\title{
Ready Student One: \\ Adventures in the New World of Virtual Pedagogy
}

\author{
James Tealy \\ Belmont University \\ This paper was presented at the 2018 International Summit of the \\ Music \& Entertainment Industry Educators Association \\ March 22-24, 2018
}

$\underline{\text { https://doi.org/10.25101/18.28 }}$

\section{Abstract}

This paper is an investigation of the challenges and opportunities associated with online 2D, Augmented Reality (AR), and Virtual Reality (VR) course content as a supplement to traditional pedagogical modalities in a workshop-style, creative course. Current trending suggests that VR users will number well over 200 million by 2020. Earnest Cline's best-selling novel Ready Player One (2011) and Steven Spielberg's cinematic adaptation of the same work (2018) have helped bring the idea of academics in a VR environment to the cultural forefront. As the use of Virtual Learning Environments (VLE's) increases, it is important to examine what pedagogical methods most effectively aid students in achieving desired learning outcomes within those environments. Is virtual pedagogy a potent educational tool or a feckless technological distraction?

In the spring of 2017, the presenter worked with Intelligent.Education and Lineage Media Solutions to produce an introductory course in Songwriting for self-guided learners in an online VLE. Forty, ten-minute sections of lecture content were recorded with a Stereoscopic 3D 4K video camera while forty (40) Xbox Kinect cameras captured holographic metadata from various angles around a green-screen video studio. Intelligent.Education has designed their courses to be consumed on VR platforms like the Oculus Rift, HTC Vive, Samsung GearVR, Playstation VR, Google Daydream, and the Microsoft Hololens. Beyond a simple survey of current technologies, Ready Student One focuses on the challenges and opportunities associated with using $2 \mathrm{D}$ video lectures, interactive 3D "props" and transcripts, and immersive Virtual Learning Environments to effectively supplement traditional pedagogical methods in workshop-style creative courses.

Keywords: augmented reality, virtual reality, virtual learning environments, songwriting, Intelligent Education, Lineage Media Solutions, music industry studies
James Tealy is a Lecturer in Songwriting in the Mike Curb College of Entertainment and Music Business at Belmont University. As a professional songwriter, James Tealy's deep list of credits cuts across several genres and includes a BMI song award winner, three \#1's at Christian radio, and songs on Dove Award and Grammy winning projects. Tealy's chart-topping songs have been recorded by Kari Jobe, Lauren Daigle, Shannon Labrie, Josh Wilson, Unspoken, Chris August, and more than 100 others. James' songs have been featured in both film and TV globally including networks NBC, CBS, Fox Sports, ABC Family, and UPN. After several years as an adjunct faculty member, Tealy joined the full-time faculty as a Lecturer in Belmont University's songwriting program in the Fall of 2016. He teaches Commercial Songwriting I, Songwriting II, Lyric Writing, Popular Melody Writing, and he leads an annual study abroad trip for songwriting majors in Uganda and Zimbabwe. Tealy also maintains a busy calendar writing with and producing a diverse group of pop, gospel, and country artists.

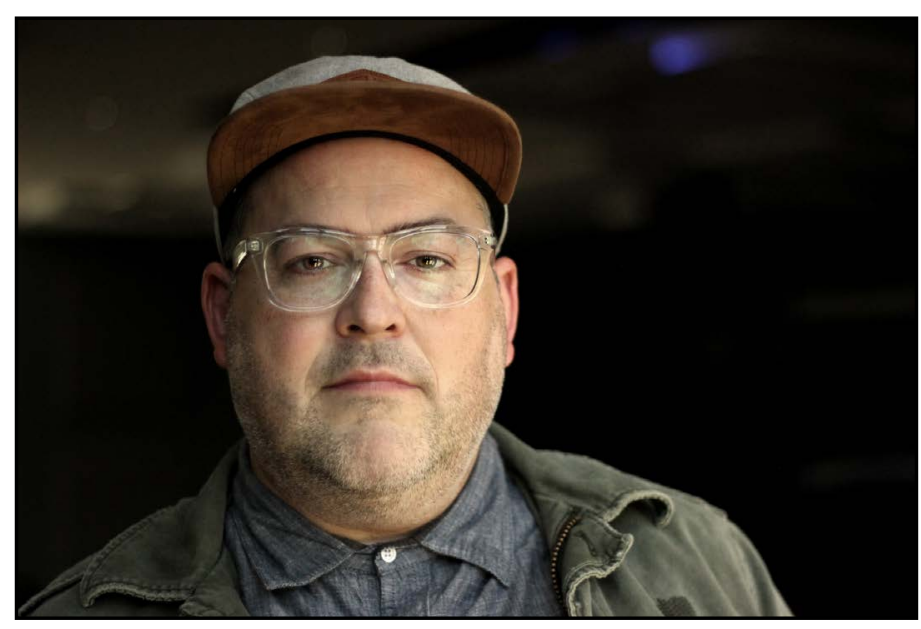




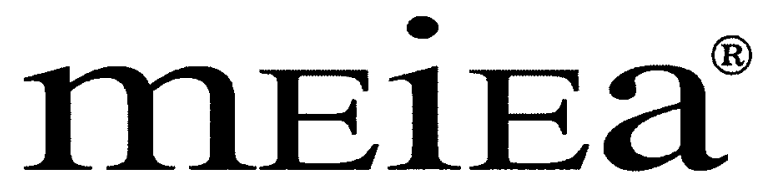

MUSIC \& ENTERTAINMENT INDUSTRY

EDUCATORS ASSOCIATION

\section{PROCEEDINGS OF THE \\ 2018 INTERNATIONAL SUMMIT}

OF THE

\section{MUSIC \& ENTERTAINMENT INDUSTRY EDUCATORS \\ ASSOCIATION}
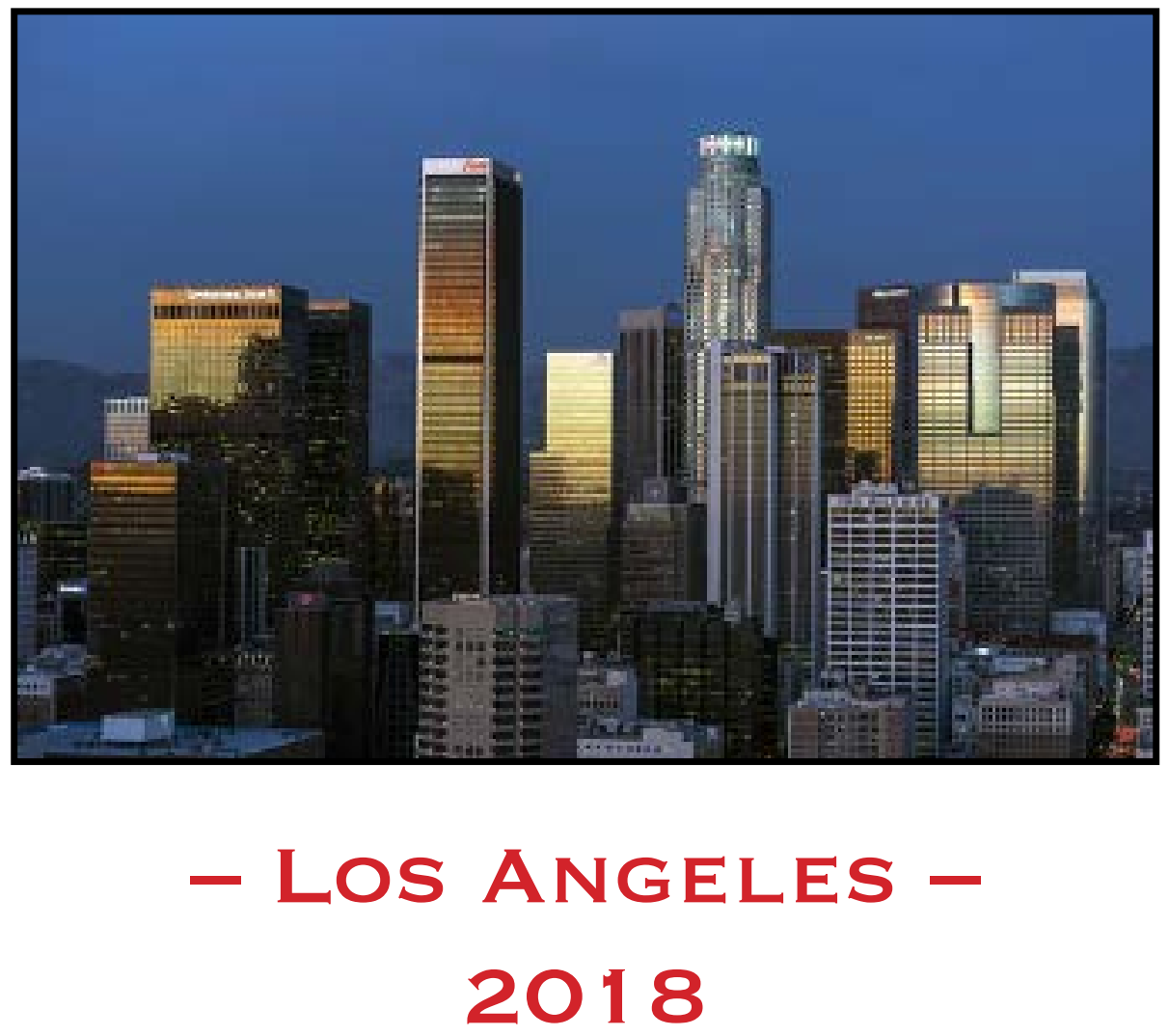

March 22 - 24, $2018 \cdot$ Embassy Suites by Hilton - Los Angeles/Glendale 